\author{
\begin{tabular}{ll} 
究 \\
\hline
\end{tabular} \\ 鼓膜穿孔の治癒過程に関する実験的研究 \\ 一上皮層および中間層の役割— \\ 竹山豊

\section{Role of Outer and Middle Layers in Healing Process of Tympanic Membrane Perforations} \\ Yutaka Takeyama \\ (Kinki University)
}

This study was designed to demonstrate how each layer of the guinea pig tympanic membrane responds during the healing of a perforation. Epidermal growth factor (EGF) and platelet-derived growth factor (PDGF) were employed to stimulate the healing process of the outer and middle layers, respectively.

The tympanic membrane was perforated by an electrical burn, and each growth factor was injected daily into the otic bulla through the external auditory meatus. The tympanic membrane perforations were examined with hematoxylin-eosin and immunohistochemically with bromodeoxyuridine. The maximal thickness of each layer at the margin of the perforation was measured light microscopically and the labeling index of bromodeoxyuridine was calculated.

Tympanic membrane perforations closed more rapidly in the PDGF-treated than in the EGFtreated ears. Significant proliferation of the epithelial layer was obtained with both treatments. However, proliferation of the middle layer was greater in the PDGF-treated than the EGF-treated ears. These results suggest that proliferation of the middle layer stimulates the epithelial layer and that proliferation of the epithelial layer directly quickens the closure of perforation of the tympanic membrane.

Key words : tympanic membrane perforation, healing process, epidermal growth factor (EGF), platelet-derived growth factor (PDGF), bromodeoxyuridine (BrdU)

\section{緒言}

鼓膜穿孔は，急性中耳炎，慢性中耳炎，鼓膜外傷など の耳鼻咽喉科疾患に拈いてしばしば遭遇するものである. 穿孔が早期に治癒する場合もあれば, 遷延する場合もあ り時に観血的治療を要することもしばしば経験される. 人に打いては治瘉過程における組織学的検討が困難で, もっぱら臨床的観察の報告が多い. 実験的鼓膜穿孔の治
癒過程の検討は Taylor $5^{1)}$ の報告以来多くの組織学的 検討2) 23) がある. 通常の創傷治癒過程と異なる点は, 鼓膜が空中にある臓器といら特殊性，すなわち下床がな い空間を充填しなければならない点である．とのため鼓 膜穿孔の治癒過程については未だ解明されていないこと がらが多く, 治療への応用の面からも基礎的研究が急が れている. 
このような事情を踏まえて, 近年創傷治癒過程に影響 を及ぼす細胞成長因子を鼓膜穿孔に作用させた報 告21 23) が散見され，鼓膜の上皮層，中間層の役割も検 討されつつある，老木 ${ }^{21)}$ は実験的鼓膜穿孔に上皮成長 因子を作用させ，上皮層の増殖促進により穿孔治癒が促 進したとしている21).

本研究では, 実験的に作成した鼓膜穿孔に上皮成長因 子 (EGF), 血小板由来成長因子 (PDGF) を作用させ, 鼓 膜の上皮層, 中間層の創傷治癒過程を刺激して穿孔治癒 過程に护ける各層の役割を組織学的に検討した．鼓膜各 層の役割がはっきりすれば，鼓膜穿孔の閉鎖を促進する 有効な手立てが議論でき臨床応用にも結びつくからであ る.

\section{実験材料および実験方法}

\section{1 . 実験動物}

ハートレー系モルモット(日本エスエルシー), 雄57匹 を使用した。この際モルモットは, 温度 $23 \pm 1^{\circ} \mathrm{C}$, 湿度 $50 \pm 10 \% ， 12$ 時間照明に制御された部屋で飼育した。飼 料は, 固形飼料(実験動物用固形飼料 $\mathrm{RC} 4$, オリエンタ 儿酵母工業)を用い，水道水を自由摂取させた。

1 週間飼育した後, 手術用顕微鏡で観察し鼓膜所見に 異常がないことを確認した。プライエル反射正常で体重 350〜400 g のモルモット，114耳を実験に供した。

\section{2 . 鼓膜穿孔の作製}

pentobarbital sodium（ネンブタール®：ダイナボット） $30 \mathrm{mg} / \mathrm{kg}$ で除痛後, 外耳道挹よび皮膚を poviodon iode （イソジン®：明治製菓）で消毒，剃毛した.

手術用顕微鏡下に十分に視野を確保した後，老木 ${ }^{21}$ の考案した穿孔作製装置で, 鼓膜緊張部後上象限を焼灼 して，一定の大きさ，形状の穿孔を作製した(図 1 ).

穿孔作製後に，感染予防のために $0.1 \%$ oxytetracycline hydrochloride（テラマイシン®：ファイザー) 水溶液を 経口投与した.

\section{3 . 穿孔径の観察}

diethyl ether (ジェチルエーテル : 和光純薬工業)麻酔 下に，接眼レンズにスケールを設置した手術用顕微鏡で， 穿孔径の変化を観察した。槌骨柄に垂直の最大の径を横 径，平行の最大の径を縦径として計測し，穿孔の治癒過 程を観察した。その際下記に記す成長因子を $23 \mathrm{G}$ カテ ラン針つき $1 \mathrm{ml}$ 注射筒で局所に投与した。

\section{4. 細胞成長因子}

epidermal growth factor (EGF : 和光純薬工業 No. 057-04111) 拈よび platelet-derived growth factor (PDGF : R \& D Systems, Inc. No. 2041-20)を $1 \%$ の penicillinstreptomycin-fungizone ${ }^{\circledR}$ mixture (Whittaker M.A. Bioproducts. Inc.) を含む生理食塩水で EGF $50 \mu \mathrm{g} / \mathrm{ml}$, PDGF $500 \mathrm{ng} / \mathrm{ml}$ の濃度の溶解液を作製した。

5 . 細胞成長因子の投与

モルモットを自然治癒群(対照群)，EGF 投与群执よ び PDGF 投与群に分け，対照群は生理食塩水を，細胞 成長因子投与群は穿孔径の観察時に経外耳道的に穿孔を 通して中耳骨包を満たし，また鼓膜表層が十分に浸るよ らに $23 \mathrm{G}$ カテラン針つき $1 \mathrm{ml}$ 注射筒を用いて $0.2 \mathrm{ml}$ 投与した。

\section{6. 連続切片の作成}

穿孔作製後，偶数日飞 5-Bromo- 2 '-Deoxyuridine (BrdU : SIGMA SIG-B5002-1) $20 \mathrm{mg} / \mathrm{kg}$ を静脈投与し て 2 時間の後に，ネンブタール $50 \mathrm{mg} / \mathrm{kg}$ の麻酔下に断 頭し，中耳骨包をとりだした。中耳骨包は95\%アルュー ル固定しプランクリュクロ液にて脱灰した。アルュール 系列で脱水しパラフィン包埋した４ $4 \mathrm{~m}$ の厚さで㮽骨 柄に垂直に穿孔部の連続切片を作製した。

7. 組織学, 免疫組織化学的観察

前項 6 。で作成した連続切片を，ヘマトキシリン・エ

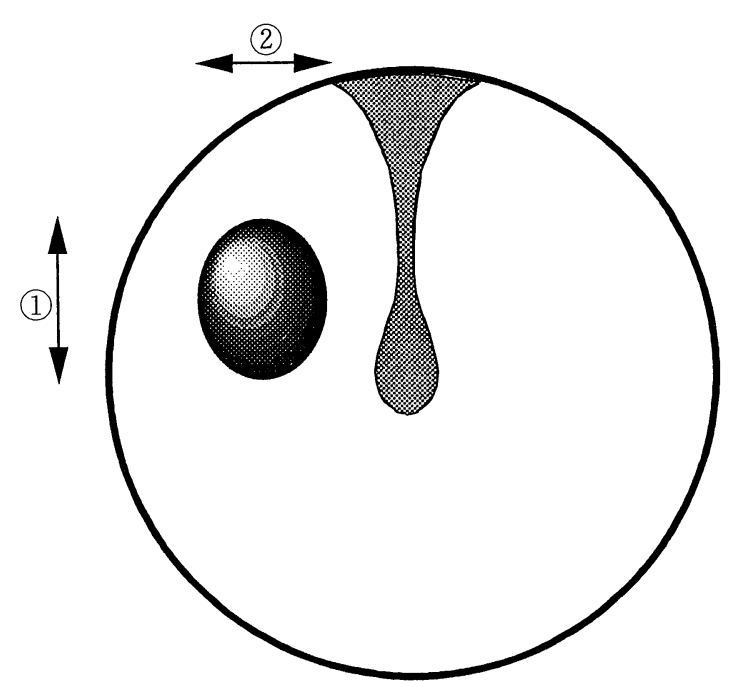

図 1 モルモット右鼓膜の後上象限に作成した穿孔のシェーマ (1)縦径 : 棺骨柄に平行の径 (2)横径 : 棺骨柄汇垂直の径 
オジン (HE) 染色拈よび $\mathrm{ABC}$ 法による抗 BrdU モノク ローナル抗体を用いて免疫組織化学染色をした.

上記で作成した $4 \mu \mathrm{m}$ パラフィン包埋切片をキシレン で脱パラフィン後, $0.3 \% \mathrm{H}_{2} \mathrm{O}_{2}$ 加メタノールで内因性 ペルオキシダーゼを除去した(20分)後, 親水化させ $2 \mathrm{~N}$ 塩酸で DNAを 1 本鎖化した(30分). 非特異反応の阻止 に10\%正常ウマ血清で被覆した(30分)後, 1 次抗体に抗 BrdU モノクローナル抗体 (Anti-BrdU Monoclonal Antibody : Becton Dickinson Immunocytometry Systems BDF-MA7580) を反応させ ( 2 時間)，2 次抗体にビオチ ン化抗体マウス IgG 抗体 (Biotinylated Anti-Mouse IgG : Vector Laboratories BA-2000)(ウマ)を結合させ (30 分), アビジンービオチン複合体 (Avidin and Biotinylated Horseradish Peroxidase : DAKO K355) を反応さ せた( 1 時間)。発色には3,3'-Diaminobenzidine tetrahydochloride (DAB : 和光純薬工業 No. 343-00901) を用い, へマトキシリンで核染色を抏こなった。

8. 細胞增殖能 Labeling Index の検討

光学顕微鏡を用いて鼓膜穿孔辺縁部の上皮層, 中間層 をHE染色標本で確認(図 2-A) し，これと対比しなが ら免疫組織化学染色標本での上皮層, 中間層を識別した。 これに基ついて各層での全細胞に対する BrdU 陽性細 胞の比率 (\%) を求めた(図 2-B). 上皮層は最先端部の 細胞が集積している領域 I と $2 \sim 3$ 層に肥厚している領

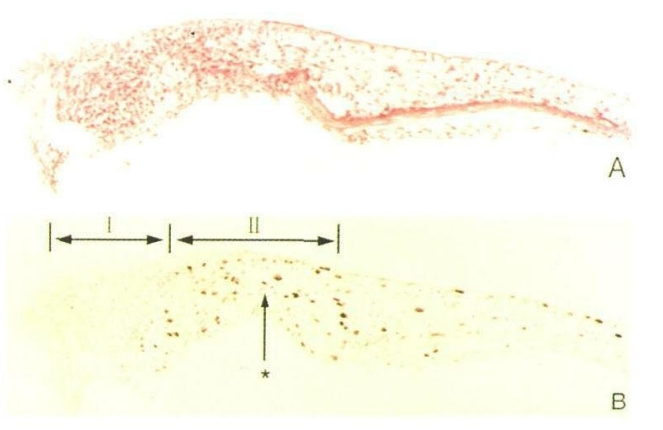

図 2 自然治癒 8 日目の $\mathrm{HE}$, 抗 BrdU 抗体に上る免疫染色 上皮層, 中間層の肥厚が $\mathrm{HE}$ 染色標本でわかる.

上皮層は最先端部の細胞が集積している領域 I と $2 \sim 3$ 層に 肥厚している領域分けた.

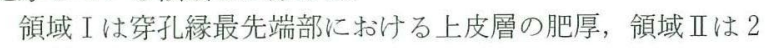
$\sim 3$ 層の上皮層の变化と中間層の肥厚で, 領域 I には BrdU 陽 性細胞はみられないが領域正には上皮層, 中間層ともに BrdU 陽性細胞をみる。

丸はBrdU 陽性細胞を示す。
域Iに分けた。中間層は上皮層で分けた領域 I，Iに一 致する領域での比率を求めた。

\section{結果}

1. 作成された鼓膜穿孔の大きさ

モルモット57匹の鼓膜に図 1 に示す様に作成した穿孔 について上下, 前後方向の直径を測定した. それぞれ桘 骨柄に平行の径を縦径, 垂直の径を横径とした。 その結 果, 縦径は $1.54 \pm 0.16 \mathrm{~mm}$, 横径は $1.30 \pm 0.21 \mathrm{~mm}$ の 穿孔が作られた。

2. 各群の治癒過程について

$2-1$ 平均閉鎖日数:

図 3，4，5 亿鼓膜穿孔の縦径, 横径の経日変化を示す. 閉鎖終了に要した日数をみると対照になる自然治癒群は 10.4 1 1.5 日 $(n=9), \quad E G F$ 投与群は8.0 1 1.2日 $(n=8)$, PDGF 投与群は6.2 20.8 日 $(\mathrm{n}=9)$ であった.いずれも 対照群に比べて有意に閉鎖日数が短縮していた( $\mathrm{t}$ 検定, $\mathrm{p}<0.05)$.

2-2 上皮層, 中間層の厚さ：

図6，7 にとれぞれ上皮層打よび中間層の厚さを老 木 ${ }^{21)}$ に準じて測定した結果を示す。

対照群については穿孔作成後 2 日目まではHE 染色 による観察で中間層の変化は汪とんどないが，辺縁部に 上皮層の細胞集積がみられた。 4 拈よび 6 日目には中間 層の肥厚が加わるが，上皮層の厚さの变化は 4 日目と 6 日目で注とんど差がなかった。 EGF 投与群については

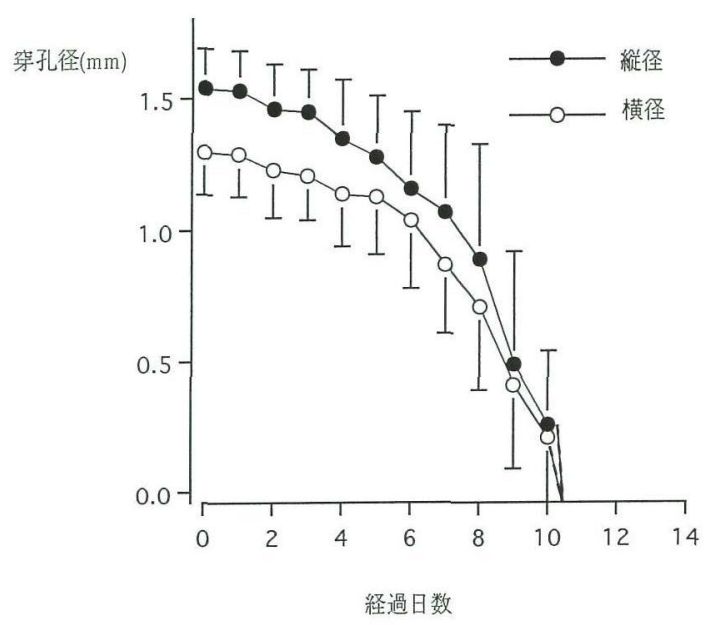

図 3 自然治癒群での鼓膜穿孔の縌径, 横径の变化 平均閉鎖日数は $10.4 \pm 1.5$ 日を要した. 
2 日目には上皮層の細胞集積がみられたが中間層の肥厚 はさ汪どみられなかった．対照群に比べ4日目，6日目 も上皮層が肥厚していた．中間層は対照群に比べ類似の 変化を示した．PDGF 投与群については2 日目より上 皮層と中間層の肥厚がみられ 4 日目には血管様の管腔も みられた。 6 日目には上皮層は目立った肥厚を示さない が中間層はさらに著しく肥厚した。

対照群に比べ $\mathrm{EGF}$ 投与群は上皮層の肥厚が著しく,

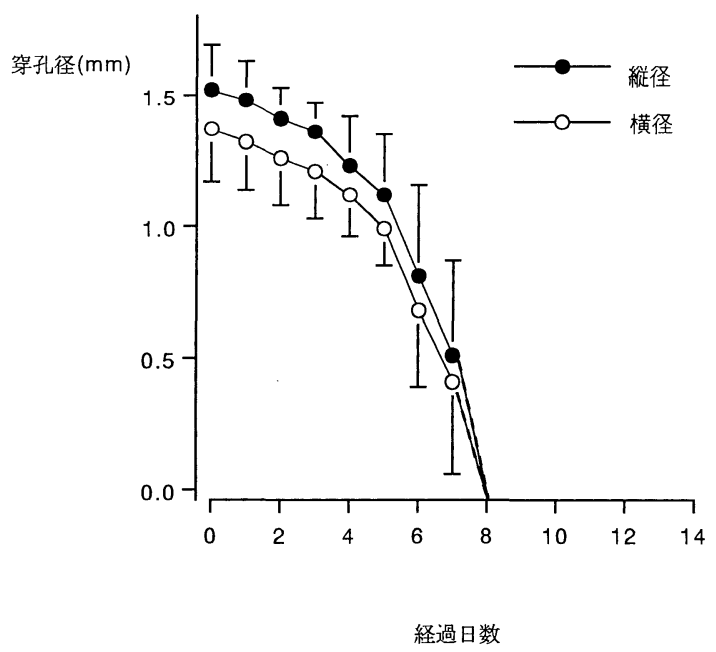

図 4 EGF 投与群での鼓膜穿孔の縦径, 横径の变化 平均閉鎖日数は $8.0 \pm 1.2$ 日で自然治癒群に比べ有意に短縮し た.

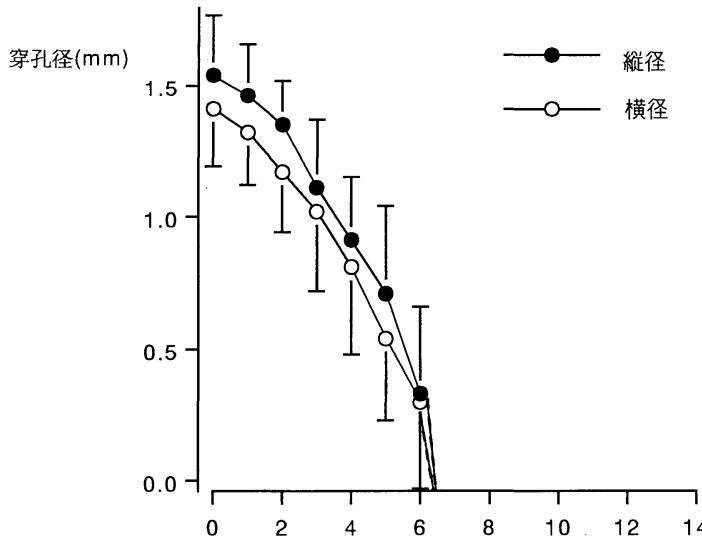

経過日数

図 5 PDGF 投与群での鼓膜穿孔の縌径，横径の変化 平均閉鎖日数は $6.2 \pm 0.8$ 日で自然治癒群に比べ有意に短縮し た.
PDGF 投与群では上皮層もやや肥厚するが中間層が著 しく肥厚する様子がわかる。

3. BrdU 陽性細胞

穿孔のない正常鼓膜では中間層に陽性細胞をみなかっ た。 上皮層に打いて $1 ， 2$ 個の陽性細胞がみられた（図 8 $-\mathrm{A}, \mathrm{B})$.

鼓膜穿孔を作成し自然経過を観察した対照群では，治 癒過程 2 日目に上皮層の辺縁部領域 I に細胞集積がみら れたがこの部位には陽性細胞はみられず，辺縁よりやや 離れた領域 II 陽性細胞がみられた(図 9-1 A，B)。4 日目にはさらに細胞集積はみられるがやはり領域 I では 陽性細胞がみられずやや離れた領域 II 陽性細胞がみら れた(図 9-2 A，B)。6日目には上皮の細胞が最先端部

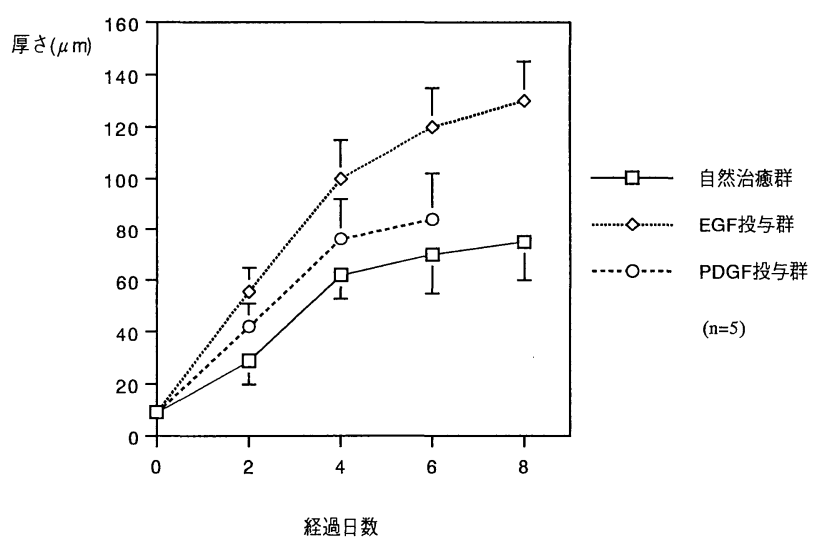

図 6 上皮層に批悼大の厚さの変化

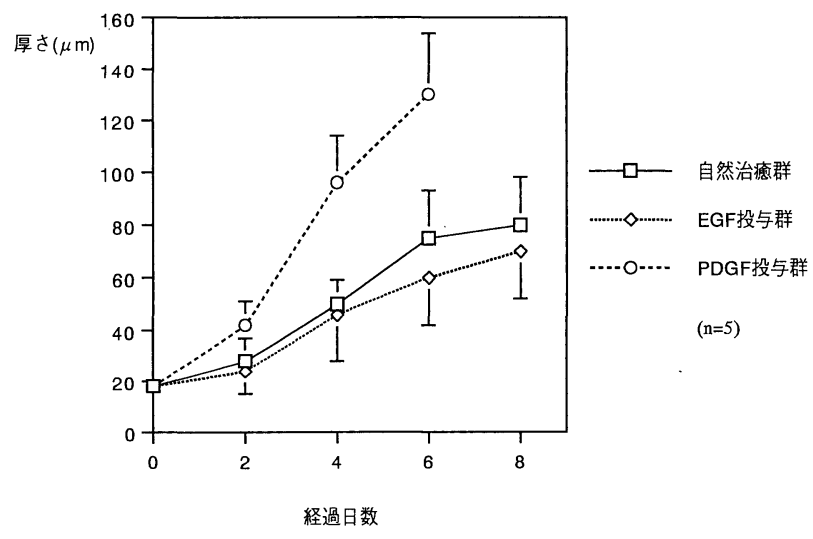

図 7 中間層に抢ける最大の厚さの変化 
を覆うように集積してくるが, やはり陽性細胞はやや離 れた領域 IIに存在寸る(図 9-3 A, B)。8日目には，上 皮層はさらに先端部を覆うように集積してくる(図 9-4

A

\section{B}

図 8 正常鼓膜緊張部 $(\times 33)$

(A：HE染色 B：抗 BrdU 抗体に上る免疫染色)
A，B）。一方，中間層では2 日目では陽性細胞は添と九 どみられない４日目に中間層が肥厚してくる時期に一 致して陽性細胞がみられるよらになってくるが，上皮層 之違い穿孔縁の肥厚した領域均一に陽性細胞がみら れた。

$\mathrm{EGF}$ 投与群では, 対照群比比較して上皮層の肥厚が 著しく，陽性細胞も上皮層飞多く又られる(図10-1 A，B， 図10-2 A, B, 圀10-3 A, B, 図10-4 A, B). PDGF 投 与群では, 中間層の肥厚が著しく, 陽性細胞も中間層に 多くみられる(図11-1 A, B, 図11-2 A, B, 図11-3 A, B).

BrdU 陽性細胞が全細胞数に占める割合，すなわち Labeling Index を求めてみると上皮層で領域 I では各群 とも陽性細胞がなからたので領域吕での值を図12に, 領 域吕での中間層の值を図13に示した，対照群の上皮層で は2 日目にやや高い傾向を示すが，4 日目以降はほぼ同

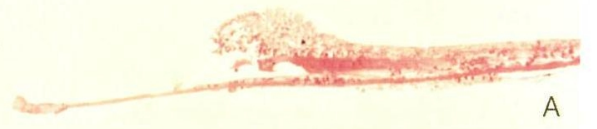

A

B

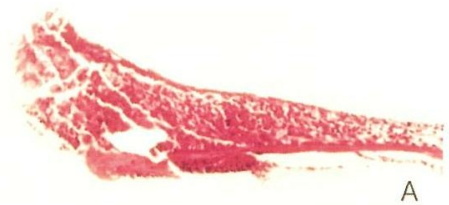

A

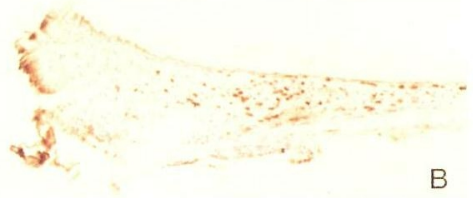

図 9-36日目

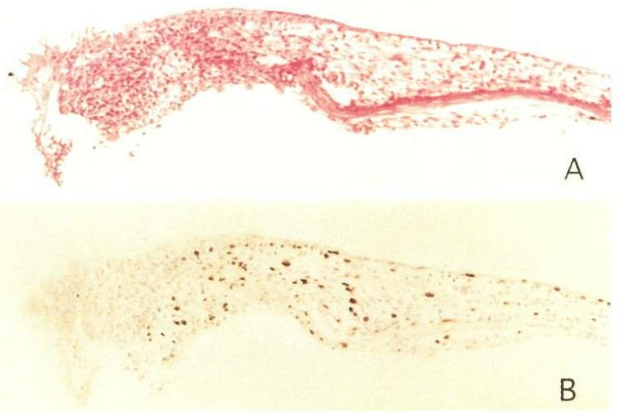

図 9-4 8日旦

図 9-24日目

図 9 自然治癒群の穿孔縁 $(\times 33)$

(A：HE 染色 B：抗 BrdU 抗体に上る免疫染色) 
じような值で経過する。一方, 中間層は治癒過程が進む とともに割合が高くなっている. EGF 投与群では，上 皮層に打いて対照群に比べ陽性細胞が多い傾向にあった が, 中間層では, むしろやや少なくなっていた. 上皮層 では経日的に減じて中間層では増加している. PDGF 投与群では上皮層の陽性率は, 対照群と同じょうに経過 し，中間層では治癒過程初期より高い值を示しているこ とがわかった。

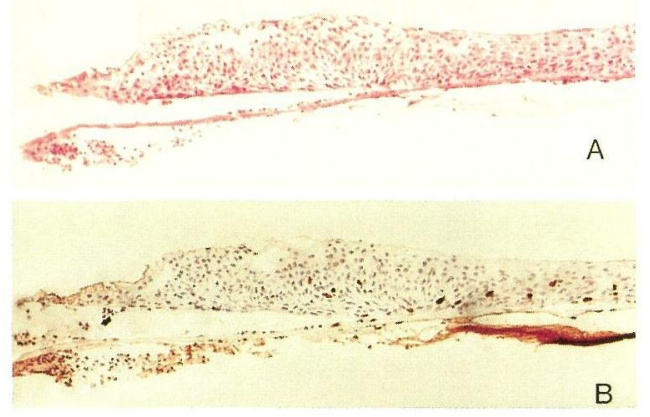

図10-12 日目
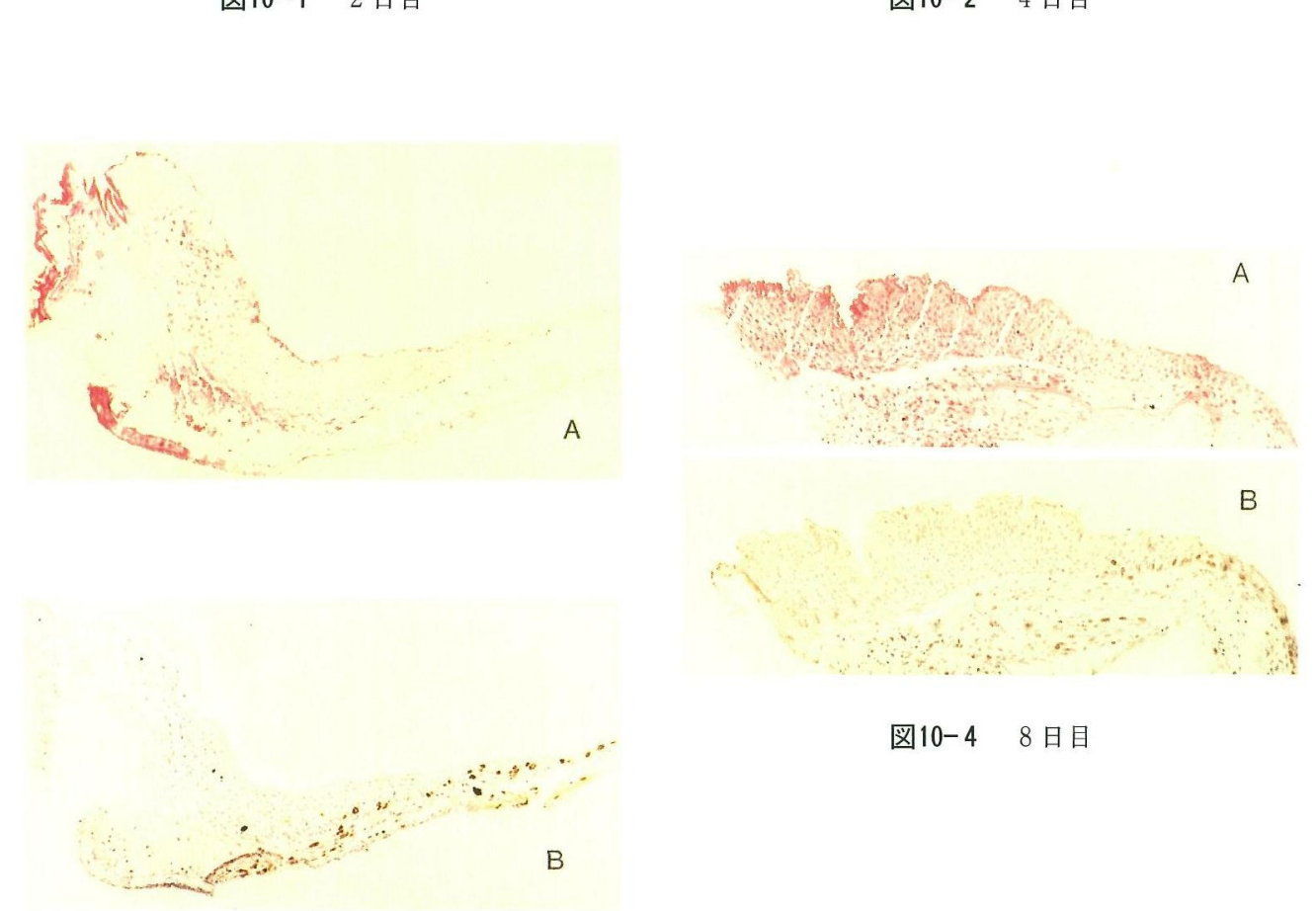

図10-4 8 日目

\section{考察}

鼓膜は生体の中で特異な組織である。それは外気中に

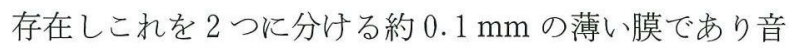
刺激で振動するからである. 解剖学的に外耳, 中耳に境 して存在し, 外耳道側の上皮層, 中耳側の粘膜層とこれ らの間に存在する固有層すなわち中間層の 3 者より成っ ている.鼓膜の創傷治瘉が他の組織の創傷治瘉と大きく 異なる点は，他の組織であれば欠損部位をすず肉芽が充

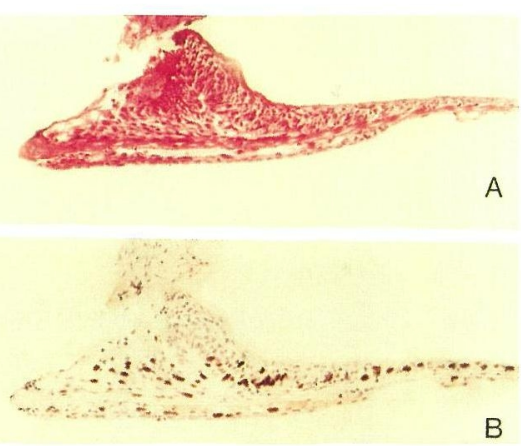

図10-2 4 日目

\section{A} B

図10-36日目

図10 EGF 投与群の穿孔縁 $(\times 33)$

(A：HE染色 B：抗 BrdU 抗体に上る免疫染色) 
填しその上を上皮が再生するが，鼓膜は下床のない空間 を埋めなければならない点である。その意味で鼓膜穿孔 の修復過程は身体の他の部位の創傷治癒過程と異なると

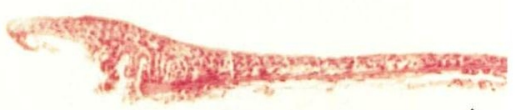

A

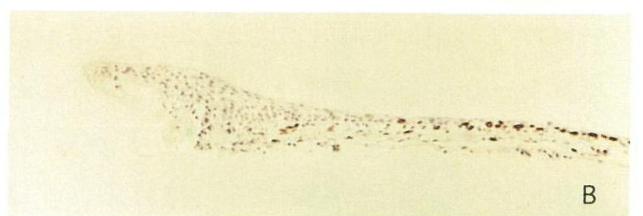

図11-12 日目
考光られ，しかも聴力の点で大切な組織ゆ光に多くの先 人の研究対象となってきた.

鼓膜穿孔の治癒に関する組織学的研究は，1965年に

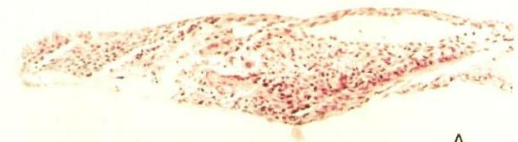

A

B

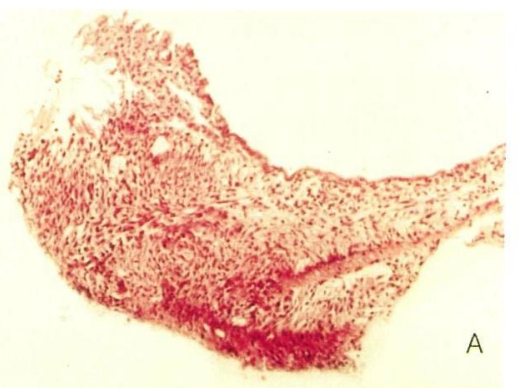

図11-24日目

図11-36日目

図11 PDGF 投与群の穿孔縁 $(\times 33)$

(A：HE 染色 B：抗 BrdU 抗体に上万免疫染色)

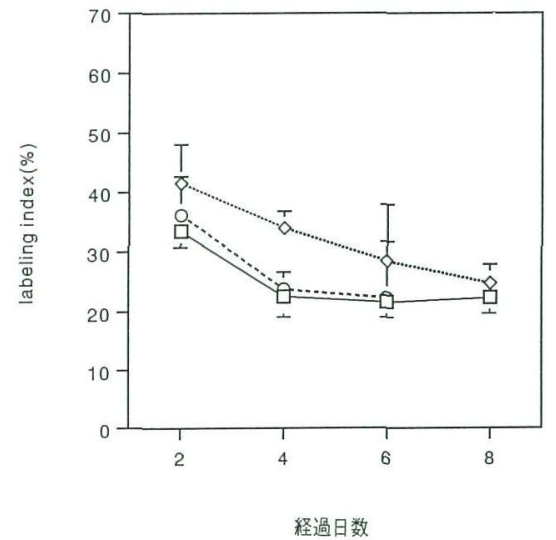

図12上皮層の Labeling Index

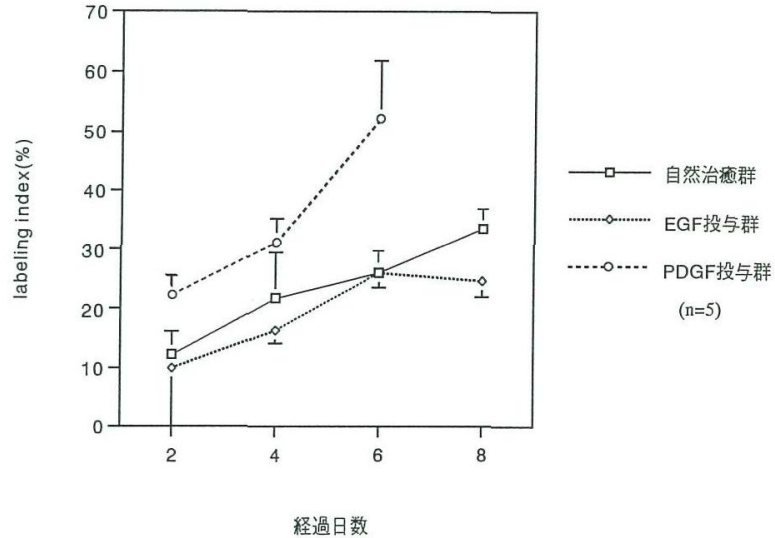

図13 中間層の Labeling Index 
Taylor $ら^{1)}$ が鼓膜穿孔の組織学的变化を報告して以来 多くの報告1) 23) がなされている．穿孔治癒過程に怙け る穿孔縁での修復像について提唱されている説は大きく 2 つに分けられる。すなわち，まず上皮層の扁平上皮過 形成が穿孔を橋渡しして閉鎖するという説(6)89911113115) と， 中間層の肉芽により穿孔閉鎖がなされその上を上皮が移 動するといら説1) 3) である．上皮層がまず穿孔を閉鎖す るといら説を支持するものが多い。

上皮層が第一義とする考光に従い，上皮層の役割につ いて検討した老木 ${ }^{21)}$ の報告において子結論が得られて いない，彼の結果は上皮層の肥厚が目立ち，EGFによ る上皮層刺激によって上皮層の肥厚が増し閉鎖も早くな ったといら報告にとどまっている21).

しかし上皮層, 中間層のいずれが閉鎖修復により重要 な役割を果たすのか，両者の関係はどらなっているのか については未だ明確ではない。

1. 今回の実験の目的

1-1 上皮層, 中間層刺激時の変化：

老木 ${ }^{21)}$ は EGF 投与により上皮層の肥厚が増し, 穿孔 閉鎖を促進すると報告した ${ }^{21)}$ しかし，中間層を肥厚さ せた場合の検討はなされていない, PDGF は, 中肧葉 由来の細胞を増殖刺激し 24$)$ 26), また創傷治癒を促進す るといら報告がある27) 311，これらの報告から鼓膜中間 層の増殖を促進することが予想されたので, この細胞成 長因子を作用させた。もし中間層の変化がみられるなら ば，EGF と比較検討することにより鼓膜穿孔治癒過程 に拈ける上皮層, 中間層が果たす役割の解明の一助にな るのではないかと考えた。

1-2 細胞增殖能の検討 :

鼓膜穿孔治癒過程を検討するのに上皮層, 中間層の厚 さの検討の久では, 肥厚が結果なのか実際增殖能が高い のかわからない。この点を考慮して細胞増殖能をみて実 際に回復機能が高いかどうかも検討した.

Thymidine の誘導体である Bromodeoxyuridine (BrdU) は DNA の合成期 ( $\mathrm{S}$ 期)の細胞核に取り込まれる. Gratzner が BrdU のモノクローナル抗体を作成し, 増殖期に ある細胞を免疫組織学的に検出する方法を報告 322 して 以来, 免疫組織化学的にも細胞增殖の動態を把握するこ とが可能になった。この成果を利用して，BrdUで DNA の合成期にある細胞つまり増殖期にある細胞を検 出し，上皮層拉よび中間層に括ける細胞増殖能の指標と した。

\section{2. 結果の考察}

2-1 穿孔閉鎖日数と上皮層, 中間層の肥厚につい $\tau:$

対照群と比べ, EGF 投与群, PDGF 投与群はいずれ も閉鎖日数が短縮していた(図 $3 \sim 5$ )が，両群ともに上 皮層が対照群に比べょり肥厚していた(図 6 )。前項に拉 いて述べたように上皮層の扁平上皮がまず穿孔を閉鎖す るといら説と一致する。しかし，穿孔閉鎖日数をみると 中間層刺激の PDGF 投与群の方が上皮層刺激の $\mathrm{EGF}$ 投与群より早く治癒している. EGF 投与群も PDGF 投 与群もコントロール群より閉鎖日数が短い。つまり両群 ともに閉鎖を促進していることがわかる。しかも，中間 層刺激の方が早く閉鎖する。注目すべきはPDGF 投与 群は $\mathrm{EGF}$ 投与群では見られなかった中間層肥厚が著明 で，しかも上皮層も肥厚した点である。この結果のみで は上皮層, 中間層の働きのいずれが中心か，互いに関連 があるのかないのかなどについてはわからない，上皮層 肥厚は中間層刺激の結果かもしれないと考光られるから である。この確認のためには上皮層, 中間層の増殖能を みることが必要となった。

実際次項に示すごとく, 増殖能が中間層では著明だが

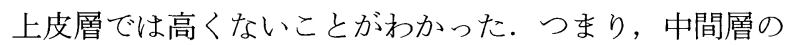
増殖が高く上皮層もとの結果肥厚したと考光る根拠があ ることが確認された。

$2-2$ 細胞増殖能の検討について :

上皮層において穿孔縁のやや後退した部位(領域 II)で BrdU 陽性細胞がみられ, 穿孔縁最先端部(領域 I ) 飞は BrdU でラベルされた細胞がみられなかった。このこと は上皮層に损いて穿孔縁最先端部(領域 I )で細胞分裂が 起こっているのではなく, 先端部よりやや離れた部位(領 域 II) に分裂の場があることを示している。つまり上皮 細胞は穿孔縁からやや離れた部位(領域II)で分裂, 増殖 が起こり細胞が穿孔縁最先端部(領域 I) に押し出されて 集積したものと考兄る. Labeling Index を経日的に見れ ば 2 日目以後徐々低下してくる．これを上皮層の肥厚 と見比べると一見矛盾するようにも見方るが，図 6 での 計測は上皮層の最大の厚さを測ったものであるのでいい かえれば穿孔縁最先端部に押し出されて集積した上皮細 胞をはかったものである。このように穿孔縁の上皮層が 経日的に肥厚してくることを説明できる.

中間層では $\mathrm{BrdU}$ 陽性細胞の局在は見られなかった。 すなわち肥厚した部位と細胞分裂の場が一致していた。 
また，Labeling Index が経日的に高くなるにしたがい中 間層の肥厚が見られた。このことから中間層では穿孔縁 に向から細胞の移動が上皮層に比べ少ないと考える.

EGF 投与群に打いては対照群と比べて上皮層では増 殖能が充進し(図12)中間層ではやや抑制された結果とな った(図13). PDGF 投与群では上皮層の増殖能は対照 群とはかわりない(図12)が中間層では著しく克進した結 果となった(図13).すなわち, 上皮層の修復が六進した 場合には穿孔治癒が促進する. しかも, 中間層の修復が 充進した場合にはより早く穿孔治癒が促進したことにな る. 中間層では細胞の移動が上皮層に比べ少ないことと 中間層が鼓膜の支持組織であることを参照すると中間層 の増殖が敨膜穿孔閉鎖には重要ではないかと考える.

2-3 閉鎖日数, 上皮・中間層肥厚および細胞增殖 能の関係 :

中間層刺激で中間層増殖能は経日的に著明な増加を続 け，中間層も著しく肥厚し上皮層もこれに伴って肥厚す る. しかし上皮層の刺激では上皮層の増殖能は当初は增 加するが経日的に低下していく，言い換えると，肥厚は 大きいが増殖能は経日的に低下して，回復能は低くなっ ていると考学られる.

つまり中間層刺激の方が細胞増殖能の増加傾向が大き く, 結果としての上皮層, 中間層肥厚が起こり, 閉鎖日 数も短くなっていると説明できる.

これは中間層刺激の方が治療薬として使えることを示 している.

\section{2-4 臨床的側面 :}

外傷性鼓膜穿孔において問題となるのは，鼓膜穿孔の 遷延化がしばしば日常の臨床で経験されることである. 一般に穿孔遺残の要因としては火傷などの特殊な外傷, 遷延する感染，全身的因子などがあげられる33) 35)。こ れらの報告では臨床的観察が主で基礎的検討はきわめて 少ない.今回の研究はこの点で意義があると考える.

次に問題となるのは, 鼓膜穿孔閉鎖後の状態に鼓膜の 菲薄化がみられ，この菲薄化には中間層が関与している

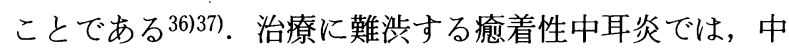
間層の欠如が関与している38).すなわち鼓膜緊張部のコ ラーゲン線維の破壊がみられ，中間層のこの組織の破壞 が正常の生理的機能をもった鼓膜から, 可動性に富んだ 鼓膜になる. また数ミリメートル水柱の圧で簡単にポケ ットを生じることになる3738). 中間層が十分に修復され れば菲薄化した鼓膜はできないはずであり，PDGFの
局所使用の安全性が確かめられれば癒着性中耳炎の治療 に応用できる可能性がある。

上皮層, 中間層増殖に及湆す PDGF, $\mathrm{EGF}$ の影響を 臨床的側面からさらに考察してみる.PDGF は軟部組 織に対する遊走能, 分裂能を活性化する事が知られてい る24) 26). また動物実験において子創傷治癒を促進する ことが報告されて和り27 31)，これらのことをふまえて 近年 PDGF の臨床応用がはじめられた。すなわち裖創 に対してPDGF-BB を局所投与して治癒を促進した報 告があり ${ }^{399}$, 耳鼻咽喉科領域において子臨床応用の可能 性が大いに期待できるものである. 実験的鼓膜穿孔にス テロイドを局所投与した際に穿孔閉鎖が遷延化した. 理 由の 1 つとして, 結合組織の重要な構成成分の 1 つであ るヒアルロン酸の合成を抑えている可能性があるという 報告がある40). PDGF はヒアルロン酸の合成を促進す る29)ことが知られて扣り穿孔治癒に打いて細胞外、ト リクスを介して働くことも考兄られる.このよらな機序 を考察すれば豉膜中間層の著明な増殖と鼓膜穿孔閉鎖促 進の成績を理解できる.

鼓膜に EGFを作用させると, 先に老木21)が報告した 結果と同様になった。すなわち, 中間層ではやや抑制さ れていた. 鼓膜以外の臟器の報告41) 45) では結合組織の 増生もみられたとある41143145) ことと異なっている。 EGF は上皮系細胞にとどまらず，各種培養細胞に対し て増殖作用を示す46) 48). しかし多くの場合, EGF 単独 の作用はわずかでありインスリン，IGF-I，レチノール 酸, アスコルビン酸などは相乗的にその作用を増強する といわれている46) 48). EGF とリセプターの結合は他の 成長因子 PDGF, fibrobrast growth factor (FGF) の前処 理により一時的に抑制される ${ }^{46)}$. 鼓膜の中間層にはこの ような成長因子が存在すると考えられる。これらのよう なことから EGF は鼓膜に执いては上皮細胞の久促進す るのかもしれない。

最近, $\mathrm{EGF}$ とそのリセプターとの関係が中耳真珠腫 において検討されている。中耳真珠腫は，慢性中耳炎の 一病態であるが，著しい骨破壊と壊死組織片を伴った上 皮の異常増殖がその特徵である.その異常増殖の手がか りに EGF とそのリセプターとの関係が示唆されてい る49) -51). たと光ば最近, EGFリセプターが中耳真珠 腫において正常皮膚よりも強くみられるとした報告, 真 珠腫上皮のほ注全層にみられたといら報告がある51)。こ の事実から EGF を鼓膜穿孔の局所へ作用させると新た 
な疾病の発生にも結びつきかねない危惧があり，臨床応 用は難しい。

以上のような事実を参照すると，鼓膜穿孔の閉鎖に中 間層増殖を刺激することが有効な手段となりらると考光 られ臨床的応用の可能性も高いと考光る.

\section{結 論}

モルモット鼓膜に一定の大きさと形状の穿孔を作成し， 以下のような結論を得た。

1 ）電気焼灼により一定の大きさ，形状の鼓膜穿孔を 作成できる.

2 ）鼓膜穿孔閉鎖に要した日数は，自然治癒群は 10.4 \pm 1.5 日, $\mathrm{EGF}$ 投与群は $8.0 \pm 1.2$ 日, PDGF 投与群は $6.2 \pm 0.8$ 日であった。 EGF 投与群，PDGF 投与群はい ずれも対照群に比べて有意に閉鎖日数が短縮した $(t$ 検 定, $\mathrm{p}<0.05)$.

3 ）自然治癒群に比べ $\mathrm{EGF}$ 投与群は上皮層の肥厚が 著しく, PDGF 投与群では上皮層も肥厚するが中間層 が著しく肥厚する.

4 ） BrdU 陽性細胞が各層での全細胞数に占める割合, すなわち Labeling Indexを求めてみると穿孔縁最先端 の上皮細胞が集積している領域 I では各群とも陽性細胞 がなかった. 上皮が $2 \sim 3$ 層に肥厚している領域IIでの 対照群の上皮層では 2 日目にやや高い傾向を示すが，4 日目以降は注涪同じような值で経過する。一方, 中間層 は治癒過程が進むとともに割合が高くなっている.

5 ） EGF 投与群では, 上皮層において対照群に比べ 陽性細胞が多い傾向にあったが，中間層では，むしろや や少なくなっていた，上皮層では経日的に減じて中間層 では増加している。

6 ）PDGF 投与群では上皮層の陽性率は, 対照群と 同じょうに経過し, 中間層では治癒過程初期より高い值 を示していることがわかった。

7 ）中間層刺激因子は細胞増殖能の増加傾向が大きく, その結果中間層，上皮層肥厚が起こり，閉鎖日数も短く なったと考察した。

\section{謝 辞}

稿を終えるに当たり, 御指導, 御校閲を賜りました近畿大学 医学部耳鼻咽喉科学教室村田清高教授に深謝いたします。また 御助言を賜りました近畿大学第 1 生化学教室西田升三博士, 耳 鼻咽搌科学教室老木浩之博士, 楠 威志博士, 中野貴之博士を
はじめ教室員各位に心から感謝いたします。

本論文の一部は, 第 38 回日本基礎耳科学会 (平成 3 年 2 月, 仙台), 7th Asia Oceania Congress of Otorhinolaryngeal Society (平成 3 年 12 月, 香港), 日本耳鼻咽㬋科学会大阪地方連合 会第245回例会 (平成 5 年 6 月, 大阪)飞扰いて発表した。

\section{参考文献}

1) Taylor $\mathrm{M}$ and McMinn RMH : Healing of experimental perforations of the tympanic membrane. J Laryngol Otol $79: 148 \sim 158,1965$.

2 ) McMinn RMH and Taylor M : The cytology of repair in experimental perforations of the tympanic membrane. $\mathrm{Br}$ J Surg $53:$ 222 232, 1966 .

3 ) Taylor $M$ and McMinn RMH : Cytology of repair in experimental perforations the tympanic membrane and its relationship to chronic perforations in man. Tr Am Acad Ophtal Otol $71:$ 802 812, 1967.

4) Rogers KAJr and Snow JBJr : Closure of experimental tympanic membrane perforations. Ann Otol Rhinol Laryngol $77: 66 \sim 71,1968$.

5 ）稲川敏文：鼓膜穿孔に関する臨床的ならびに実験的研究. 日耳鼻 $72 ： 687 \sim 718,1969$.

6) McIntire C and Benitez JT : Spontaneous repair of the tympanic membrane; histopathological studies in the cat. Ann Otol Rhinol Laryngol 79 : 1129 1131, 1970.

7 ) Hildmann $\mathrm{H}$ and Steinbach E : Experimental studies on closing of artificial eardrum perforations in rabbits. J Laryngol Otol $85:$ 1173 1176, 1971.

8 ) Reijnen $\mathrm{CJH}$ and Kuijpers W : The Healing pattern of the drum membrane. Acta Otolaryngol (Stockh) Suppl 287 : $1 \sim 74,1971$.

9 ) Clowson JP and Litton WB : The healing process of tympanic membrane perforations. Tr Am Acad Ophth Otol $75: 1302 \sim 1312,1971$.

10) McMinn RMH : Electron microscopic observations on the repair of perforated tympanic membranes in the guinea pig. J Anat $120: 207 \sim 217,1975$.

11) Reeve DRE : Repair of large experimetal perforations of tympanic membrane. J Laryngol Otol $91: 767 \sim 778,1977$.

12) Boedts D and Ars B : Histopathological research on eardrum perforations. Arch Otorhinolaryngol 215 : 55 59, 1977.

13) Boedts D : The tympanic epithelium in normal and pathological conditions. Acta Otorhinolaryngol Belg 32 : 296 419, 1978.

14) Fry TL, Chen B, Fischer ND, et al : Evaluation of otic drops on infection and healing of traumatic tympanic mem- 
brane perforations. Laryngoscope $89: 818 \sim 821,1979$.

15) Stenfors LE, Calsöö B, Salén B, et al : Repair of experimental tympanic membrane perforations. Acta Otolaryngol (Stockh) $90: 332 \sim 341,1980$.

16) Söderberg $O$, Hellström $S$ and Stenfors LE : The healing pattern of experimental heat myringotomy. Rev Laryngol Otol Rhinol (Bord) $106: 81 \sim 85,1985$.

17) Stenfors LE, Bergherm L, Bloom GD, et al : Exogeneous hyaluronic acid (Healon ${ }^{\circledR}$ ) accelarates the healing of experimental myringotomies. Auris Nasus Larynx 12 : Suppl $1: 214 \sim 215,1985$.

18）朴 茂男: 実験的鼓膜切開創の修復に関する電子顕微鏡的 観察. 日耳鼻 $89: 843 \sim 853,1986$.

19) Hellström $S$ and Laurent $C:$ Hyaluronan and healing of tympanic membrane perforations; an experimental study. Acta Otolaryngol (Stockh) Suppl $442: 54 \sim 61,1987$.

20) Laurent $C$, Hellström $S$ and Fellenius $E$ : Hyaluronan improves the healing of experimental tympanic membrane perforations. Arch Otolaryngol Head Neck Surg 114 : 1435 1441, 1988.

21）老木浩之：モルモット鼓膜穿孔の治瘉過程に护ける細胞成 長因子の影響. 近畿大医誌 $14: 485 \sim 499,1989$.

22) O'Daniel TG, Petijean M, Jones SC, et al : Epidermal growth factor binding and action on tympanic membrane. Ann Otol Rhinol Laryngol 99 : 80 84, 1990.

23) Mondian M, Saffiendine S and Uziel A : Fibroblast growth factor improves the healing of experimental tympanic membrane perforations. Acta Otolaryngol (Stockh) 111 : 337 341, 1991.

24) Grotendorst GR, Seppä HEJ, Kleinman HR, et al : Attachment of Smooth muscle cells to collagen and their migration toward platelet-derived growth factor. Proc Natl Acad Sci USA 78 : 3669 3672, 1981.

25) Deuel TF, Senior RM, Griffin GI, et al : Chemotaxis of monocytes and neutrophils to paltelet-derived growth factor. J Clin Invest $69: 1046 \sim 1049,1982$.

26) Seppä H, Grotendorst G, Martin GR, et al : Platelet-derived growth factor is chemotactic for fibroblasts. J Cell Biol $92: 584 \sim 588,1982$.

27) Pierce GF, Mustoe TA, Senior RM, et al : In vivo incisional wound healing augmented by platelet-derived growth factor and recombinat c-sis gene homodimeric proteins. J Exp Med 167 : 974 987, 1988.

28) Pierce GF, Mustoe TA, Lingelbach J, et al : Platelet-derived growth factor and transforming growth factor- $\beta$ enhance tissue repair activities by unique mechanisms. J Cell Biol 109 : 429 440, 1989.

29) Mustoe TA, Purdy J, Pierce GF, et al : Reversal of im- paired wound healing in irradiated rats by platelet-derived growth factor-BB. Am J Surg $158:$ 345 350, 1989.

30) Pierce GF, VandeBerg J, Mustoe TA, et al : Platelet-derived growth factor-BB and transforming growth factor-beta 1 selectively modulate glycosaminoglycans, collagen, and myofibroblasts in excisional wounds. Am J Pathol 138 : 629 646, 1991.

31) Lynch SE, Colvin RB and Antoniades $\mathrm{HN}$ : Growth factors in wound healing. J Clin Invest $84: 640 \sim 646,1989$.

32) Gratzner HG : Monoclonal antibody to 5-bromo- and 5iododeoxyuridine; a new reagent for detection of DNA replication. Science $218: 474 \sim 476,1982$.

33）山本令子, 高山幹子, 石井哲男: 外傷性鼓膜穿孔. JOHNS $3: 679 \sim 684,1987$.

34）小野寿之, 村上匡孝, 内田真哉：外傷性鼓膜穿孔. JOHNS 8 : 925 930, 1992.

35）南谷肇子, 村田清高, 太田文彦, 他 : 外傷性鼓膜穿孔症例 の統計的観察. 耳鼻臨床 補 $45 ： 48 \sim 53,1991$.

36) Govaerts PJ, Jacob WA and Marquet J : Histological study of the thin replacement membrane of human tympanic membrane perforations. Acta Otolaryngol (Stockh) $105: 297 \sim 302,1988$.

37) Luntz $M$ and Sadé J : Daily fluctuations of middle ear pressure in atelectatic ears. Ann Otol Rhinol Laryngol 99 : 201 204, 1990.

38) Sadé J : Atelectatic tympanic membrane; histologic study. Ann Otol Rhinol Laryngol 102 : 712 716, 1993.

39) Robson MC, Phillips LG, Pierce GF, et al : Platelet-derived growth factor BB for the treatment of chronic pressure ulcers. Lancet $339: 23 \sim 25,1992$.

40) Spandow $O$ and Hellström $S$ : Animal model for persistent tympanic membrane perforations. Ann Otol Rhinol Laryngol $102: 467 \sim 472,1993$.

41) Flanklin JD and Lynch JB : Effects of topical applications of epidermal growth factor on wound healing. Plast Reconstr Surg 64 : 766 770, 1979.

42) Niall M, Ryan GB and O'Brien BM : The effect of epidermal growth factor on wound healing in mice. J Surg Res $33: 164 \sim 169,1982$.

43) Buckley A, Davidson JM, Woodward SC, et al : Sustained release of epidermal growth factor accelerates wound repair. Proc Natl Acad Sci USA 82 : 7340 7344, 1985.

44) Laato M, Niinikoski J, Lebel L, et al : Stimulation of wound healing by epidermal growth factor. Ann Surg $203: 379 \sim 381,1986$.

45) Buckley A, Davidson JM, Woodward SC, et al : Epidermal growth factor increases granulation tissue formation dose dependently. J Surg Res $43: 322 \sim 328,1987$. 
46) 今井康夫 : Epidermal Growth Factor. 細胞成長因子(日本 組織培養学会編). $20 \sim 30$ 頁, 朝倉書店, 東京, 1984.

47）今井康夫 : Epidermal Growth Factor. 細胞成長因子 part II (日本組織培養学会編). 10 15頁. 朝倉書店, 東京, 1987.

48）對馬敏夫：成長因子. ホルモンと臨床 $33: 1105 \sim 1111$, 1985.

49）後藤友佳子：上皮成長因子（epidermal growth factor： EGF) と真珠腫組織 一第一報 ; 活動型真珠腫と非活動型 真珠腫に括ける EGF の局在の比較一. 日耳鼻 $93: 1186$ ～ 1191, 1990.
50）後藤友佳子：上皮成長因子 (epidermal growth factor： EGF） と真珠腫組織一第二報；重層扁平上皮細胞角化層 に打㥩 EGF の局在一. 日耳鼻 $93: 1192 \sim 1199,1990$.

51) Bujía J, Holly A, Schultz P, et al : Aberrant expression of epidermal growth factor receptor in aural cholesteatoma. Laryngoscope 103 : 326 329, 1993.

$\left(\begin{array}{l}\text { 原稿受付 : 平成 } 6 \text { 年 } 9 \text { 月 } 2 \text { 日 } \\ \text { 原稿採択 : 平成 } 6 \text { 年 } 9 \text { 月 } 28 \text { 日 急載 } \\ \text { 別刷請求先 : 竹山 豊 } \\ \text { 干5 } 58 \text { 大阪狭山市大野東 } 377-2 \\ \text { 近畿大学医学部耳鼻咽㮢科学教室 }\end{array}\right)$

